\title{
An Empirical Analysis on the Capital Structure of Chinese
}

\section{Listed IT Companies}

\author{
Yuanxin Liu \& Jing Ren \\ School of Business Administration, North China Electric Power University \\ Beijing 102206, China \\ E-mail: yuanxin09@126.com \\ Yan Zhuang \\ Shenyang Institute of Aeronautical and Engineering \\ Shenyang 110034, China
}

\begin{abstract}
The idea of this study is to identify the determinants of corporate financial structure for the IT industry in China which is a promising service industry but is facing challenges and risk in the Global financial turmoil. In this paper, we analyze the determinants of the capital structure for a panel of 92 IT companies listed in the China stock exchange. Six traditional explanatory variables are adopted in the study, including size, profitability, tangibility, liquidity, profit growth rate and growth opportunity. Linear regressions are used to study the effects of the factors. It is found that the size of companies are positively related to leverage, while growth and profitability, liquidity, profit growth rate and growth opportunity are negatively associated with leverage. The sign of these relations suggest that both the pecking order theory and trade off hypothesis are at work in explaining the capital structure of IT companies.
\end{abstract}

Keywords: Capital Structure, IT company, China capital market

\section{Introduction}

The empirical literature suggests a number of factors that may influence the financial structure of a company. As argued by Timan and Wessels(1988)and Harris and Reviv(1991), the choice of explanatory variables in the analysis of crosssectional variation in capital structure is fraught with difficulty. Rajan and Zingales (1995) in their study of capital structure in the G-7 economies find gearing in the UK to be positively related to tangibility (the proportion of fixed to total assets) and the size of the company, but negatively related to the level of profitability and the market-to-book ratio. The results of Rajan and Zingales (1995) are highly dependent upon the precise definition of gearing being examined.

Most of the empirical evidence on capital structure comes from studies of the determinants of corporate debt ratios e.g.Tima and Wessels(1988), Rajanand Zingales (1995), Graham(1996)and studies of issuing firms' debt vs. equity financing choice Marsh(1982),Jallilv and and Harris(1984). Horakimian et al.(2003)have successfully identified firm characteristics such as size, R\&D intensity, market-to-book ratio of assets, stock returns, asset tangibility, profitability and the marginal tax rate as important determinants of corporate financing choices. Baner(2004)examined the capital structure of listed companies in Visegrad countries(Czech Republic, Hungary, Poland and Slovak Republic).In his study, six potential determinants of capital structure are analyzed: size, profitability, tangibility, growth opportunities, non-debt tax shields and volatility.

Much of the empirical research on the determinants has been directed largely towards companies in developed countries. However, there has been relatively little research done to this date on companies listed in countries experiencing transition from a planned to market economic system like China. Chen (2004)is the first to study determinants of firm-level capital structure in China using a balanced panel of 77 listed companies. Huang and Song (2006)use a data set, which contains the market and accounting data, from more than 1000 Chinese listed companies from 1994 to 2000 ,to document the characteristics of these firms in terms of capital structure. They reported that the leverage in Chinese firms increases with firm size, non-debt tax shields and fixed assets, and decreases with profitability and correlates with industries. LinPing et al.(2005)also conducted an investigation and show that the capital structures differ according to size.

As an important impetus for economic growth in modern times, the IT industry has greatly promoted sustainable 
development in China. As the business environment, the requirement of management is substantial different with other traditional industries, the capital structure of IT companies has its specific characteristics. It is imperative for IT companies to be able to finance their activities and grow over time if they are ever to play an increasing and predominant role in creating value, providing employment as well as income in terms of profits, dividends and wages to households, and expanding the size of the directly productive sector in the Dynamic economy. It is important in this regard to understand how IT companies in China to finance their operations by examining their capital structure determinants. This article will identify the determinants and their power over the enterprise values which in turn help IT companies to programmatically build up a healthy and fruitful capital structure and maintain a stable prosperity and growth.

\section{Research methodology}

\subsection{Sample set}

This paper uses market and accounting data of more than 90 Chinese listed IT companies from the China Stock Market in the period between 2004 to 2007.To ensure the accuracy and subjectiveness, the industry classification of those companies are all aligned with the industry classification published by the China Securities Regulatory Commission(CSRC)in 2001. Meanwhile, the selection of the companies follow the below rules :1.In order to reduce the distraction of the data from new IPO companies, only companies listed before Dec 31th,2003 are enrolled into the study.(2).All the companies that been marked as 'ST' during the period are removed from the sample to avoid confusion. As a result, the final sample set consists of a balanced panel of 92 firms. And the 92 companies left includes 17 from Shenzhen A share,50 from Shanghai A shares, 18 from SMB shares ,5 from the Third shares, one from Shenzhen B shares and one from Shanghai B share. The 92 companies cover the four major sub-industries of IT industry which are Telecommunication and Equipment manufacturer; Computer and related manufacturer; Telecommunication service industry including telecommunication service and other communication service ;Computer based Application service.

\subsection{Sample characteristics}

\subsubsection{Overall features of the descriptive statistics over the samples.}

Insert Table 1 here

As we can see from the table 1, the debt ratio of the 92 corporations in the four years' period are $43.5287 \%(2004)$, $44.3584 \%(2005), 45.7696 \%(2006)$ and $43.9847 \%$ (2007) with the average at $44.4104 \%$ which is lower than the average of all the listed companies in Chinese Security Market. We can also know that the ratio maintain a medium level variation during the 4 years' period.

\subsubsection{The stability of the overall features in the listed companies.}

To have a better understanding of the stability of debt ratio of the sample during the four years of the IT industry as a whole and the four sub-industries, a illustration are drawn as below.

\section{Insert Figure 1 here}

As we can see from this figure, the IT industry as a whole has remained relatively stable and all the sub-industries also keep a similar stability with the maximum deviation less than 5 percent. Among the four sub-industries, the most stable one is the telecommunication \& equipment manufacturer and Computer and related manufacturer.

\subsection{Regression models and variables}

Since the sample contains data across firms and over time, the panel data method is employed. This thesis adopts a method with one-time access and multiple analysis. We will wipe off some variable according to the result and economic meaning until the model can be checked out from perspective of statistics and economics. The model is as follow:

$$
Y=C+a X_{1}+b X_{2}+c X_{3}+d X_{4}+e X_{5}+f X_{6}
$$

$\mathrm{C}$ is a constant, $a, b, c, d, e_{\text {and }} f$ are separately the coefficient of $X_{1}, X_{2}, X_{3}, X_{4}, X_{5}$ and $X_{6}$

Y: capital structure with debt ratio as the index

$\mathrm{X} 1$ : corporation size with the logarithm of asset as the index. Companies with larger size tend to be more diversified and hence their cash flow are less volatile. Size may then be inversely related to the probability of bankruptcy (Titman and Wessels, 1988; Rajan and Zingales, 1995). Ferri and Jones (1979) suggest that large firms have easier access to the markets and can borrow at better conditions. Overall, larger firms with less asymmetric information problems should tend to have more equity than debt and thus have lower leverage. 
X2: Profitability with earnings before interest and tax(EBIT)scaled by total assets as the index. In contrast to theoretical studies, most empirical studies show that leverage is negatively related to profitability. Friend and Lang (1988),and Titman and Wessels(1988)obtain such findings from US firms. Kester (1986) finds that leverage is negatively related to profitability in both the US and Japan. More recent studies using international data also confirm this finding (Rajan and Zingales(1995),and Wald(1999)for developed countries).Long and Maltiz (1985)find leverage to be positively related to profitability,but the relationship is not statistically significant. Wald (1999)even claims that "profitability has the largest single effect on debt/asset ratios."

X3: Tangibility with capital asset and stocks ratio as the index. Tangible assets are likely to have an impact on the borrowing decisions of a firm because they are less subject to informational asymmetries and usually they have a greater value than intangible assets in case of bankruptcy. Additionally, the moral hazard risks are reduced when the firm offers tangible assets as collateral, because this constitutes a positive signal to the creditors who can request the selling of these assets in the case of default. As such, tangible assets constitute a good collateral for loans.

X4: Liquidity using the Liquidity ratio as the index. Using liquidity ratio as an indicator, Wang Juan and Fenglin Yang (2002) confirmed a trade-off relationship between the collateral value of assets and debt ratio.Their finding is almost contrary to the pecking order pattern of financing. They argued that even if listed firms in China are capable of repaying their debts, they would still prefer to employ equity finance.

X5: Growth potential with the profit growth rate after tax as the index. The agency theory states that the growth potential is negatively correlated with debt asset ratio. This theory assumes that firms with a high growth potential are more flexible with regard to their options for future investment projects. In the case of a large number of debt obligations, these firms may have to relinquish potentially beneficial projects that in turn may lead to insufficient investments.

X6: Growth opportunity with the rate of main operation growth as the index. For companies with growth opportunities, the use of debt is limited as in the case of bankruptcy, the value of growth opportunities will be close to zero. Jung et al.(1996)show that firms should use equity to finance their growth because such financing reduces agency costs between shareholders and managers, whereas firms with less growth prospects should use debt because it has a disciplinary role(Jensen,1986; Stulz,1990).

\section{Regression results}

Table 2 report the sample correlation coefficients between all the variable and capital structure. Table 3 report the sample correlation coefficients between all the variable and capital structure after wiping off the constant. Table 4 represent the result that wiped off the net assets and the main operation growth rate.

From the model, we can see that the coefficient of determination is 0.923 and it shows that the model can ideally fit the sample data. With $\mathrm{F}$ equal to 263.512 , it means that all the independent variables and the dependent variable have a significant linear correlation. With $\mathrm{D}-\mathrm{W}$ equal to 2.182 and $\mathrm{dL}=1.59, \mathrm{dU}=1.73$ when $\mathrm{N}=92$ and $\mathrm{K}=4$ (the number of variables),we can see no self-correlation. Meanwhile, as all VIF is less than 10,we see no multiple collinear. Residuals Distribution show no heteroscedasticity.

Hence, we are confident that the equation is as follow:

$$
Y=3.85 X_{1}+40.09 X_{3}-1.85 X_{4}-0.005 X_{5}
$$

\section{Conclusion}

Through the empirical study of the 92 IT corporations, we find the result as follow:

The corporation size and capital structure have positive correlation but this kind of correlation is not significant. The positive impact of size on leverage is consistent with the results of many empirical studies(Rajan and Zingales, 1995; Booth et al.2001; Frank and Goyal,2002).The larger a company's scale is, the more stable its profitability will be as the larger company has lower risk of bankrupt and it has a higher debted capability. Also large companies have easier access to the bond markets. Although this kind of correlation is not significant and its effect on capital structure is as distinct as those IT companies in developed countries, we can expect the correlation between scale and capital structure will become more and more significant within Chinese IT corporations as the globalization are affecting Chinese economics more deeply and more companies are participating in the international competitions.

The profitability and capital structure has negative correlation. Retained profit is the quickest and easiest source of finance for most companies compared with new equity issuance due to the transaction costs associated with share issuance and the restrictions on firms' operating performance for applying for new equity issuance. Furthermore, since the majority of new equity is issued through share allotments, new issues usually lead to a decline in the firm's stock price. Therefore retained profit is the preferred primary method of raising additional capital. Meanwhile, most of the management of the Chinese listed companies prefers equity financing rather than debt financing because the former is not binding as a company with higher profit are easily to obtain equity financing than those elsewise. 
However, the relationship is not significant. The main reason is that Chinese companies pay more attentions to how to get fund rather than which way is the most efficient way to obtain the funding. So we can easily understand when these companies have the characteristics as follow:

--The indebted financing is high while equity capital is low.

--External financing is high while internal fund is low.

--Indirect fund is high while direct fund is low.

Asset value and capital structure has distinct positive correlation, it can be interpreted by the theory of agency costs, bankruptcy theory and pecking order theory. And we can also get the same conclusion from the characters of capital structure in IT corporations.

Liquidity and capital structure has negative correlation: if a company has more current assets, the fund can be used to invest instead of external short-term indebted fund. And we see that this assumption is validated by the empirical study.

Development potential (measured by Profit growth rate)has negative correlation with capital structure, but it is not significant. Development potential is the accumulation capability. Though the trade-off theory and pecking order theory disagree on this point, both of them can explain the situation with IT corporations while the pecking order theory is more suitable.

Growing opportunities and capital structure has negative correlation, but it is not significant.

According to the trade-off theory, firms holding future growth opportunities tend to borrow less than firms holding more tangible assets because growth opportunities cannot be collateralised. Further, agency theory argues that firms have a tendency to expropriate wealth from debt holders (Myers,1977; Jensen,1986). The high market capitalizations in China may also indicate that the growth opportunities associated with listed firms have been recognized by the capital market; therefore, banks are willing to assign higher valuations to highly levered firms and issue more long-term debt to finance the firms' growth opportunities.

From the result of the regression, we can see that the coefficient are big except the growth rate which mean that those factor has significant affect over the capital structure. That imply that certain firm-specific factors that affect firms' leverage in the Western countries also affect Chinese companies' leverage. This has shown that Chinese-listed firms have followed the basic rules of a market economy despite the state controlling ownership.

\section{Acknowledgment}

This research is supported by National Natural Science Foundation of China №70501010; by the Natural Science Foundation of Beijing city under Grant №9072009 ;by the elitist plan of Beijing under Grant №20071D1600900432.

\section{References}

Belsley, D.A., Kuh, E., and Welsch, R.E. (1980). Regression Diagnostics, John Wiley \& Sons,Inc., New York, NY.

Booth, I., V. Aivazian, A. (2001). Demirguc-Kunt and V. Maksimovic, Capital Structure in Developing Countries. Journal of Finance, 56, pp. 87-130.

Brealy, R. A. and S. C. Myers. (2003). Principles of Corporate Finance, 7th ed. McGraw-Hill.

Chen, J. (2004). Determinants of capital structure of Chinese-listed companies. Journal of Business Research, Vol. 57, pp.1341-51.

Chen, J. J. (2003). Determinants of Capital Structure of Chine-listed Companies. Journal of Business Research, 57,pp. 1341-1351.

Fama, E. F. and K. R. French. (2002). Testing Trade-Off and Pecking Order Predictions, about Dividends and Debt. The Review of Financial Studies, 15, pp. 1-33.

G. O. Young. (1964). Synthetic structure of industrial plastics(Book style with paper title and editor), in Plastics, 2nd ed. Vol. 3, J. Peters, Ed. New York: McGraw-Hill, pp. 15-64.

Harris, M. and A. Raviv. (1991). The Theory of Capital Structure. Journal of Finance, 46, pp. 297-355.

Harris, M.and Raviv. (1991). The theory of capital structure. Journal of Finance, 46, pp.334.

He, Qing. (2007). Corporation Financing policy and system study of capital structure, Economy science press.

Huang, R. and J. Ritter. (2005). Test the Market Timing Theory of Capital Structure, Working Paper, University of Florida.

Huang, Samuel G.H., and Frank M. Song. (2006). The Determinants of Capital Structure: Evidence from China. China Economic Review, 17, 14-35. 
Kong, Xiaowen. (2005). Choice of China corporation's capital structure- theory and emprical analysis [Phd thesis]. Guangdong Jinan University.

Li, Guozhong. (2007). Capital structure determination Multilayer dynamic study. Beijing: CPU press, $167-207$.

Li, Zhiqiang \& Dong, Yanan. (2003). Study of IT corporation's affection factors on capital structure. Transaction of Neimengguo financing and economy institute, (2).

Miller, Merton H. (1977). Debt and Taxes. Journal of Finance, 2, No.2, pp.261-275.

Modigliani Franco and Miller, Merton H. (1967). Some Estimates of the Cost of Capital to the Eletalric Utility Industry, 1954-1957. American Economic Review, 57, pp.1288-1300.

Titman and Wessels. (1998). The determinants of capital structure choice. Journal of Finance, 43, pp.17.

Wang, Huacheng. (2006). Financing management study. Beijing, China Finance Press.

Yan, Haojun. (2006). China corporation's capital structure study based on dynamic adjust model[Phd thesis].Shanghai: Institute of economy and management in TongJi University.

Zhang, Xiyu. (2003). IT corporation' capital structure affection factors. Statistics and decision making, 7.

Table 1. Overall features of the Descriptive statistics(Unit: \%)

\begin{tabular}{c|c|c|c|c|c}
\hline & Sample Size & Min & Max & Mean & Standard dev. \\
\hline 2004 & 92 & 2.72 & 84.08 & 43.52 & 17.951 \\
\hline 2005 & 92 & 0.35 & 86.87 & 44.35 & 17.394 \\
\hline 2006 & 92 & 6.25 & 76.32 & 45.76 & 16.409 \\
\hline 2007 & 92 & 7.04 & 72.01 & 43.98 & 15.052 \\
\hline Avg. & 92 & & 44.41 & \\
\hline
\end{tabular}

Table 2. First regression Coefficients(a)

\begin{tabular}{|c|c|c|c|c|c|c|c|}
\hline \multirow[b]{2}{*}{ Model } & \multicolumn{2}{|c|}{$\begin{array}{l}\text { Unstandardized } \\
\text { Coefficients }\end{array}$} & \multirow{2}{*}{\begin{tabular}{|l} 
Std. Co. \\
Beta
\end{tabular}} & \multirow[b]{2}{*}{$t$} & \multirow[b]{2}{*}{ Sig. } & \multicolumn{2}{|c|}{ Collinearity Statistics } \\
\hline & B & Std.Error & & & & & \\
\hline (Constant) & 11.793 & 33.579 & & 0.351 & 0.726 & & \\
\hline Logarithm of total asset & 2.646 & 3.64 & 0.065 & 0.727 & 0.469 & 0.783 & 1.278 \\
\hline Profit rate of net assets & -0.073 & 0.123 & -0.072 & -0.596 & 0.553 & 0.427 & 2.342 \\
\hline capital asset and stocks ratio & 39.98 & 10.184 & 0.333 & 3.926 & 0 & 0.872 & 1.147 \\
\hline Liquidity & -1.896 & 0.411 & -0.415 & -4.616 & 0 & 0.773 & 1.293 \\
\hline Profit growth rate after tax & -0.004 & 0.002 & -0.182 & -1.521 & 0.132 & 0.439 & 2.278 \\
\hline Main operation growth rate & -0.003 & 0.021 & -0.012 & -0.14 & 0.889 & 0.885 & 1.131 \\
\hline
\end{tabular}

Table 3. Second regression Coefficients(a,b)

\begin{tabular}{|c|c|c|c|c|c|c|c|}
\hline \multirow[b]{2}{*}{ Model } & \multicolumn{2}{|c|}{$\begin{array}{l}\text { Unstandardized } \\
\text { Coefficients }\end{array}$} & \multirow{2}{*}{\begin{tabular}{|c|}
$\begin{array}{c}\text { Standardized } \\
\text { Coefficients }\end{array}$ \\
Beta
\end{tabular}} & \multirow[b]{2}{*}{$\mathrm{t}$} & \multirow[b]{2}{*}{ Sig. } & \multicolumn{2}{|c|}{ Collinearity Statistics } \\
\hline & $\mathrm{B}$ & Std.Error & & & & & \\
\hline Logarithm of total asset & 3.915 & 0.446 & 0.759 & 8.782 & 0 & 0.12 & 8.364 \\
\hline Profit rate of net assets & -0.067 & 0.121 & -0.027 & -0.553 & 0.581 & 0.379 & 2.642 \\
\hline Capital assets \& stocks ratio & 39.942 & 10.131 & 0.303 & 3.942 & 0 & 0.151 & 6.64 \\
\hline Liquidity & -1.839 & 0.375 & -0.184 & -4.905 & 0 & 0.632 & 1.583 \\
\hline Profit growth rate after tax & -0.004 & 0.002 & -0.072 & -1.634 & 0.106 & 0.456 & 2.194 \\
\hline Main operation growth rate & -0.002 & 0.02 & -0.003 & -0.09 & 0.928 & 0.809 & 1.237 \\
\hline
\end{tabular}


Table 4. Third regression Coefficients $(\mathrm{a}, \mathrm{b})$

\begin{tabular}{|c|c|c|c|c|c|c|c|}
\hline \multirow[b]{2}{*}{ Model } & \multicolumn{2}{|c|}{$\begin{array}{l}\text { Unstandardized } \\
\text { Coefficients }\end{array}$} & \multirow{2}{*}{$\begin{array}{c}\text { Standardized } \\
\text { Coefficients }\end{array}$} & \multirow[b]{2}{*}{$\mathrm{t}$} & \multirow[b]{2}{*}{ Sig. } & \multicolumn{2}{|c|}{$\begin{array}{l}\text { Collinearity } \\
\text { Statistics }\end{array}$} \\
\hline & B & Std.Error & & & & & \\
\hline Logarithm of total asset & 3.854 & 0.429 & 0.747 & 8.978 & 0 & 0.127 & 7.901 \\
\hline Profit growing rate after tax & -0.005 & 0.002 & -0.091 & -3.039 & 0.003 & 0.976 & 1.025 \\
\hline Liquidity & -1.857 & 0.367 & -0.186 & -5.057 & 0 & 0.646 & 1.548 \\
\hline Capital assets \& stocks rate & 40.094 & 10.007 & 0.305 & 4.007 & 0 & 0.152 & 6.6 \\
\hline
\end{tabular}

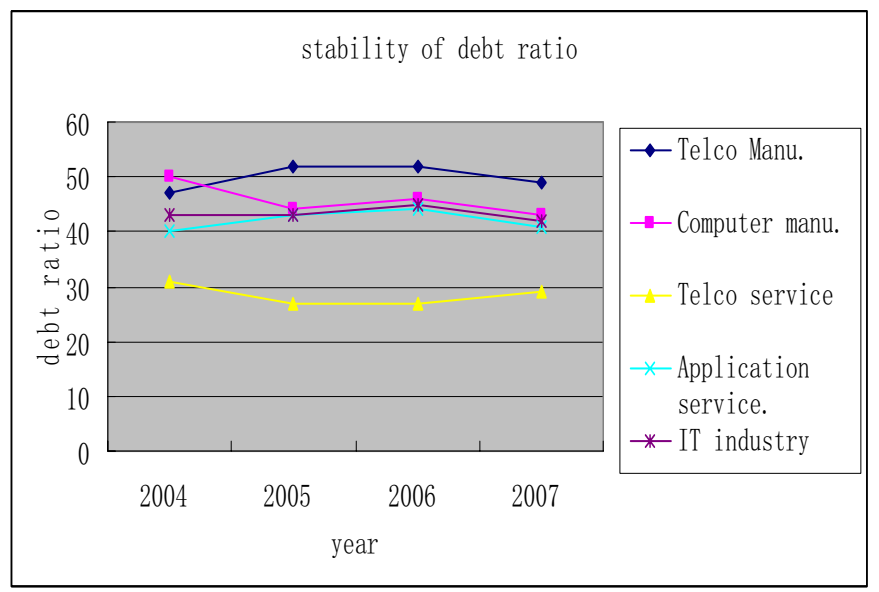

Figure 1. Stability of the Overall features in IT industry 